\title{
Association of burnout syndrome and global self-esteem among Polish nurses
}

\author{
Ewa Kupcewicz¹, Marcin Jóźwik²
}

\author{
${ }^{1}$ Department of Nursing, Faculty of Health Sciences, Collegium Medicum University \\ of Warmia and Mazury, Olsztyn, Poland \\ 2Department of Gynecology and Obstetrics, School of Medicine, Collegium Medicum, \\ University of Warmia and Mazury, Olsztyn, Poland
}

Submitted: 14 July 2019

Accepted: 15 September 2019

Arch Med Sci 2020; 16 (1): 135-145

DOI: https://doi.org/10.5114/aoms.2019.88626

Copyright $\odot 2019$ Termedia \& Banach

\section{Abstract}

Introduction: The development of burnout syndrome is conditioned by demographic variables, personality-related variables, ways of coping with difficulties and organizational/professional factors. Burnout is a psychological syndrome of emotional exhaustion and fatigue that may occur in people working with other people in certain ways. Understanding the role of global self-esteem and sociodemographic and work environment-related variables in the development of burnout syndrome in Polish nurses was the aim of this study.

Material and methods: The study included 1,806 nurses working in 23 hospitals in north-eastern Poland. The average age was $44.7 \pm 7.96$ years. The questionnaire was of a proprietary design. The Copenhagen Burnout Inventory Scale and the Rosenberg SES scale were used.

Results: With regard to contact with patients, symptoms of burnout were present in $28.2 \%$ of respondents. Furthermore, $27 \%$ of respondents showed work-related burnout and personal burnout was indicated in $21 \%$ of them. Almost half of the respondents (46.6\%) evaluated their self-esteem at an average level. The obtained results of the regression analysis indicated that global self-esteem was a predictor of professional burnout in nurses. Global self-esteem has important consequences in many aspects of the mental condition. It was found that global self-esteem is a key factor influencing personal burnout symptoms, and its modification may be used as a preventive measure.

Conclusions: Developing personal resources and deriving benefits from them may be important in the prevention of burnout syndrome. This study indicated the need to carry out preventive measures in the workplace to protect nurses from burnout.

Key words: nurses, occupational health, nursing, burnout syndrome, work environment, workforce issues, global self-esteem.

\section{Introduction}

The literature review confirms that the most commonly presented definition is the concept of burnout by Christina Maslach. According to this definition, "burnout is a psychological syndrome of emotional exhaustion, depersonalization and a reduced sense of personal accomplishment that can occur in people who work with other people in a certain way" [1]. An interesting approach to the problem of burnout has

\author{
Corresponding author: \\ Ewa Kupcewicz MD, PhD \\ Department of Nursing \\ Faculty of \\ Health Sciences \\ Collegium Medicum \\ University of Warmia \\ and Mazury \\ 14 C Żołnierska St \\ 10-561 Olsztyn, Poland \\ Phone: +48 696076764 \\ E-mail: ekupcewicz@wp.pl
}


been presented by Danish researchers, acknowledging that exhaustion and fatigue is the basis of burnout. On this basis, Kristensen et al. developed a research tool called the Copenhagen Burnout Inventory (CBI) to measure burnout [2]. The CBI is a questionnaire available in the public domain that encompasses three sub-dimensions. Individuals may be compared and evaluated regardless of the occupational status using the personal burnout scale. The latter is meant to describe how tired or exhausted a person is. In the CBI inventory, this quality could be named fatigue, weakness, exhaustion or any other comparable term, and the person's burnout dimension is characterized as "the degree of physical and psychological fatigue and exhaustion that is experienced by the person" [2, 3]. Client-related burnout is "the degree of physical and psychological fatigue and exhaustion that is perceived by the person as related to his/ her work with clients" [2, 3]. The quoted authors analyzed how people perceive a relation between their exhaustion and their "people work". Finally, work-related burnout is defined as "the degree of physical and psychological fatigue and exhaus tion that is perceived by the person as related to their work" [2, 3]. A new approach to work-related burnout distinguishes three characteristic symptoms: exhaustion, detachment and ineffectiveness at work [4]. Exhaustion means a reduction in cognitive and emotional resources as well as low energy levels and a decline in physical strength. Further, lack of involvement at work may manifest itself in detachment from providing a professional function [4]. Professions such as a nurse or a midwife are associated with a high risk of work-related burnout. Practicing these professions is associated with exposure to ergonomic, psycho-social and work organization related factors, which may have a negative impact on health. Work-related burnout among nurses and midwives as a psychological phenomenon has been studied and evaluated for many years. However, under dynamic changes in the work environment on a global scale, a contemporary nurse or midwife has to face an increasing number of threats resulting in an array of difficult circumstances often beyond human physical and psychological capacity. A review of the available literature clearly demonstrates the diversity of the problem of burnout. A cross-sectional survey of 598 Norwegian midwives showed that a personal or work-related burnout was reported by approximately $20 \%$ of them. Less than $5 \%$ of them reported a client-related burnout [5]. Also, in studies conducted at four German hospitals it was found that the workload was the strongest predictor of emotional exhaustion. Attention was also paid to the negative relationship between freedom of professional decision-making and emotional exhaustion [6]. In Shanghai, a study conducted on a group of 527 nurses showed high levels of emotional exhaustion. In 74-76\% of nurses, the Demand/Control ratio was higher than 1, and in 13-27\% of nurses the Effort/Reward ratio was higher than 1 . High levels of burnout strongly associated with work-related stress were described in nurses from Shanghai [7]. Studies conducted by Shamali et al. confirmed that in nurses with fixed shift schedules, the emotional exhaustion was significantly higher than in nurses with random shifts, but no significant difference was found between personal accomplishment and depersonalization, or between nurses with fixed morning and fixed night shifts [8]. In other studies, researchers attempted to determine the burnout level in midwives employed in a maternity ward in South East Queensland, Australia. It this study, almost $30 \%$ of the examined midwives showed moderate-to-high levels of burnout, about half the study group scored moderate-to-high for personal burnout and another half scored high for work-related burnout [9]. The study results confirm the significance of work environment-related, sociodemographic and personal variables in the occurrence (and exacerbation) of work-related burnout syndrome. In studies conducted in Andalusia, a group of 676 nurses was studied and manifested average-to-high burnout levels. "There were statistically significant differences in burnout levels associated with the following variables: age, gender, marital status, having children, the level of healthcare, the type of work shift, healthcare service areas and conducting administrative tasks. Burnout was also associated with personality-related variables" [10]. The results of the available studies show that people with high self-esteem believe that they have high social skills and can easily establish new relationships. This may translate into better adaptation to new situations in the work environment and a greater ability to cope with difficulties [11]. It may be assumed that a high level of self-esteem in nurses favors the assessment of the work environment as a friendlier, safer and less stressful environment. Moreover, it could be a factor in decreasing the severity of (protection from) the negative effects of fatigue and tiredness at work in the form of professional burnout syndrome. Based on the above-mentioned studies, the risk of development of work-related burnout in the contemporary complicated work environment generates high psychological labor costs. The literature review showed a paucity of data from Poland on the relationship and role of global self-esteem with the occurrence of burnout syndrome among nurses. The activities related to ensuring a safe working environment encourage researchers to assess the role of the personal re- 
sources of health care workers in the process of professional burnout, among which global self-esteem may play a significant role.

The aim of the study was to investigate the role of global self-esteem and sociodemographic and work environment-related variables in the development of burnout syndrome among Polish nurses.

\section{Material and methods}

\section{Design}

For the measurement of the variables, a questionnaire of our own design, containing questions about demographics and the work environment was used. The study exploited the Copenhagen Burnout Inventory (CBI) by Tage S. Kristensen et al., which consists of 19 statements about attitudes toward work and feelings associated with it [2]. The $\mathrm{CBI}$ encompasses three scales for personal burnout (6 questions), work-related burnout (7 questions), and client-related burnout (6 questions) for use in different domains. All three scales assured a high level of internal reliability, with small non-response rates. The scales enabled a good differentiation between occupational groups in the human services, showing an expected pattern regarding correlations with other measures of fatigue and psychological well-being. In addition, the above scales had a good prediction value for sickness leaves, sleep problems, need for painkillers and intention to quit a job. A follow-up study showed that the burnout levels changed in a significant number of those surveyed. The $\mathrm{CBI}$ questionnaire psychometric properties were satisfactory, and Cronbach's $\alpha$ relating to the specific dimensions of each burnout was very high, ranging from 0.85 to 0.87 . The respondents gave answers on a 5-point scale. A range of score responses ranged from 0 to 100 points, where 100 $=$ all/to a very large extent, 75 = often/largely, $50=$ sometimes/a bit, 25 = rarely/small degree, $0=$ never/almost never/to a very small extent [2]. The average ratings for each component criteria for burnout were calculated: average $\leq 45$ - no burnout, $46<$ average $\leq 55$ - risk of burnout, average $>55-$ the presence of burnout [12]. Measurement of the global level of overt self-esteem, treated as a relatively stable attitude towards "Me", was done using Morris Rosenberg's Self-Esteem Scale (SES) in the Polish adaptation by Dzwonkowska et al. [13]. The scale consists of 10 propositions, all of them being diagnostic, and the person tested indicates how much he/she agrees with each of them. Answers are scored on a 4-point scale (ranging from $1=$ strongly disagree to 4 = strongly agree). The result is a sum of points; the higher the points, the higher the level of self-esteem. Possible results fall within the range of 10 to 40 points. The general indicator of the global self-esteem level was transformed into standardized units, which were interpreted according to the characteristics of the sten scale. The sten scale contains 10 units and each unit equals 1 sten. Results from 1 to 4 stens were considered as low, ranging from 5 to 6 stens as average, and between 7 and 10 stens were considered high. The adapted Polish SES scale showed good psychometric properties with Cronbach's $\alpha$ in the different study groups varying from 0.81 to 0.83 [13].

\section{Data collection}

The study was conducted with voluntary, random sampling. Empirical material was collected from June 2013 to January 2015. The study was conducted at the workplace of nurses, with the consent of hospital directors. Thanks to the institutional nature of hospitals, the selection of the samples was random. A questionnaire campaign was conducted in 23 health-care facilities in north-eastern Poland: (7) Olsztyn, (2) Elbląg, (2) Ełk, (1) Działdowo, (1) Nowe Miasto Lubawskie, (1) Kętrzyn, (1) Szczytno, (1) Biskupiec, (1) Iława, (1) Ameryka, (1) Ostróda, (1) Pisz, (1) Mrągowo, (1) Nidzica, (1) Giżycko. In total, 2,885 questionnaire forms were distributed among medical personnel (nurses/midwives). Upon collection of data and elimination of faulty questionnaires filled in by nurses, 1,806 (62.6\%) questionnaires were qualified for further analyses. The return percentage varied depending on the health-care facility and ranged from $25.3 \%$ to $87.5 \%$.

The main criteria for inclusion in the study were at least 1 year of full-time employment as a nurse based on an employment contract and informed consent to participate in the study. Respondents were informed about the purpose of the survey, and had the opportunity to ask questions and receive explanations. Questionnaires were filled in anonymously and the collected empirical data were coded into a computer program. The results of the study were presented collectively.

\section{Ethical approval}

The study was conducted in line with the principles stated in the Declaration of Helsinki. Senate Research Ethics Committee of J. Rusiecki Olsztyn University College, Poland issued a positive opinion (No. 11/2016) on the ethical aspects of the research project. The Faculty of Health Sciences, Collegium Medicum University of Warmia and Mazury in Olsztyn covered the costs of publishing. The research was implemented as part of the project (62-610-001).

\section{Statistical analysis}

The statistical analysis employed descriptive statistic and sten scale scores. In order to evaluate 
the dependence of the variables, the chi-square $\left(\chi^{2}\right)$ test of independence was used. For variables not showing a normal distribution, non-parametric tests were used in the analyses. To detect the impact of socio-demographic and work environment variables related to burnout, the Kruskal-Wallis $(H)$ test was used. The correlations between variables were analyzed using Spearman's rank correlation test $(r)$. The results were presented based on the classification of Guilford's correlation force. A multiple regression analysis was used to construct a random variable estimation model. The $p$-level $<0.05$ was considered significant. Statistical calculations were performed using the Statistica $13 \mathrm{PL}$ package (StatSoft).

\section{Results}

\section{Characteristics of the studied group}

The study involved 1,806 nurses. The average age was $44.7 \pm 7.96$ years with a median of 45.0. Respondents were mostly aged $41-50(n=$ $862 ; 47.7 \%)$, resided in a city $(n=1,432 ; 79.3 \%)$, were married ( $n=1,414 ; 78.3 \%$ ), regarded their financial situation as sufficient $(n=774 ; 42.8 \%)$ and had 2 children $(n=833 ; 46.1 \%)$. Every third person had a secondary medical education $(n=$ $665 ; 36.8 \%)$, a group slightly smaller had college/post-secondary education ( $n=371 ; 20.5 \%)$ and $25.4 \%(n=458)$ had completed university studies (a bachelor's degree in nursing). The average number of years of work as a nurse was $22.5 \pm 9.45$ years with a median of 24 . The most numerous group consisted of persons working in the profession for 21 to 30 years $(n=734$; $40.7 \%)$. More than three-quarters of respondents worked in shifts, including 'on call' time at night $(n=1,367 ; 75.7 \%)$, mostly as a regular nurse $(n=$ $1,613 ; 89.3 \%)$.

Most of the respondents ( $n=804 ; 44.5 \%$ ) worked in wards/clinics with a medical profile, and fewer $(n=574 ; 31.8 \%)$ in wards with a surgical profile. $13.6 \%(n=245)$ of the respondents worked in intensive care, anesthesiology and surgery units.

\section{Characteristics of burnout and self-esteem}

For individual components of burnout, average values were calculated: for the work-related burnout component $46.13 \pm 15.37$, burnout in contacts with patients $45.80 \pm 18.25$ and personal burnout $43.62 \pm 15.88$. As shown in statistical analyses, half of the respondents demonstrated no personal burnout (50.7\%; $n=915), 46.1 \%(n=832)$ reported that they did not feel the symptoms of work-related burnout and slightly fewer reported lack of burnout in contacts with patients (44.7\%; $n=807)$. More than a quarter of respondents claimed that they were in danger of burnout in all areas, and showed the following values: $28.2 \%$ for personal burnout and $27.0 \%$ for work-related burnout and burnout in contact with patients. The presence of symptoms of personal burnout was indicated by $21.1 \%(n=381)$ of respondents, while far more nurses reported symptoms of work-related burnout $(27.0 \% ; n=487)$ and burnout in contact with patients $(28.3 \% ; n=512)$. The average rate of global self-esteem in the studied group was $27.3 \pm 10.06$ with a median of 30.0 and was comparable to the results obtained during normalization testing in adults (30.11 \pm 4.08$)$ [13]. In the current study, $46.6 \%(n=841)$ of nurses rated their global level of self-esteem as average, and every fifth person indicated a high or low self-esteem globally ( $24.0 \% ; n=433$ vs. $29.5 \% ; n=532$ ). The obtained values of coefficients of the chisquare independence test indicate the presence of statistically significant relationships at the $p<$ 0.001 level of significance for global self-esteem (independent variable) and professional burnout (dependent variable) in all three components: personal burnout, burnout at work and burnout in contacts with patients (Table I). Based on the value of $r$ for Spearman's rank correlation test, a statistically significant negative correlation between the examined variables was found. The strength of the correlation between global self-esteem and personal burnout was weak, but it was highly significant $(r=-0.26 ; p<0.001)$. In the other two cases, a very weak relationship was observed (for

Table I. Significance of relations of global self-esteem and burnout

\begin{tabular}{|c|c|c|c|}
\hline \multirow[t]{2}{*}{ Burnout type } & $\begin{array}{c}\text { Chi-square test } \\
\text { of independence }\left(\chi^{2}\right)\end{array}$ & Kruskal-Wallis test $(\mathrm{H})$ & $\begin{array}{c}\text { Spearman's rank correlation } \\
(r)\end{array}$ \\
\hline & \multicolumn{3}{|c|}{$P$-value } \\
\hline Personal burnout & $\begin{array}{l}145.3 \\
0.001\end{array}$ & $\begin{array}{l}69.00 \\
0.001\end{array}$ & $\begin{array}{l}-0.26 \\
0.001\end{array}$ \\
\hline $\begin{array}{l}\text { Work-related } \\
\text { burnout }\end{array}$ & $\begin{array}{l}81.3 \\
0.001\end{array}$ & $\begin{array}{l}38.74 \\
0.001\end{array}$ & $\begin{array}{l}-0.18 \\
0.001\end{array}$ \\
\hline $\begin{array}{l}\text { Burnout in } \\
\text { contacts with } \\
\text { patients }\end{array}$ & $\begin{array}{l}70.6 \\
0.001\end{array}$ & $\begin{array}{l}38.56 \\
0.001\end{array}$ & $\begin{array}{l}-0.16 \\
0.001\end{array}$ \\
\hline
\end{tabular}

Statistically significant: $p<0.001$. 
burnout associated with work $r=-0.18$; $p<0.001$ and in contacts with patients $r=-0.16 ; p<0.001$ ) (Table I). It may be concluded that nurses with lower global self-esteem often experience symptoms of burnout. It is worth noting, however, that they often observe symptoms of personal burnout rather than burnout associated with work and in contacts with patients (Table I).

\section{Significance of the relationship between components of burnout, demographic and work-related factors}

In subsequent analyses using the $\chi^{2}$ independence test, the relationship between sociodemographic and work environment variables and the three components of occupational burnout were examined. The pool of analyzed independent variables included age, marital status, financial situation, education, number of years of work in the profession, system of work, type of position occupied and profile of activity of the ward/clinic. Only in the case of one variable determining the marital status of respondents was there no statistically significant relationship with personal burnout, work-related burnout or burnout in relations with patients. On the other hand, as a result of the analysis, statistically significant interrelations between the financial situation $\left(\chi^{2}=83.11 ; p<\right.$ $0.001)$, education of the respondents $\left(\chi^{2}=19.05\right.$; $p<0.02)$, type of position $\left(\chi^{2}=13.61 ; p<0.001\right)$, branch activity profile/clinics $\left(\chi^{2}=14.17 ; p<0.03\right)$ and personal burnout characterized by prolonged physical and mental fatigue and exhaustion were observed (Table II). Slightly more associations were observed between independent variables and a component of occupational burnout associated with work characterized by prolonged physical and mental fatigue and exhaustion in connection with work performed. During the analysis of the values of $\chi^{2}$ independence test coefficients, statistically significant relations were found between the nurse's age $\left(\chi^{2}=33.87 ; p<\right.$ $0.001)$, financial situation $\left(\chi^{2}=79.08 ; p<0.001\right)$, education $\left(\chi^{2}=41.41 ; p<0.001\right)$, number of years in the profession $\left(\chi^{2}=54.73 ; p<0.001\right)$, type of position occupied ( $\left.\chi^{2}=10.32 ; p<0.005\right)$, ward/ clinic activity profile $\left(\chi^{2}=17.04 ; p<0.009\right)$ and occupational burnout (Table II). The analysis also revealed significant relationships between independent variables and the third area of occupational burnout manifested by physical and mental fatigue or exhaustion experienced by the nurse in contact with patients. The following values were recorded: for age $\left(\chi^{2}=16.94 ; p<0.009\right)$, financial situation $\left(\chi^{2}=78.41 ; p<0.001\right)$, education $\left(\chi^{2}=\right.$ $22.28 ; p<0.004)$, seniority $\left(\chi^{2}=36.71 ; p<0.001\right)$, work system $\left(\chi^{2}=6.41 ; p<0.04\right)$ and work-station category $\left(\chi^{2}=9.26\right.$; $\left.p<0.009\right)$ (Table II). In the next step of the statistical analysis, the Kruskal-Wallis test was used to study the differences between variables. No statistically significant difference was found between the work system and personal burnout, the profile of the ward/clinic activity and burnout related to work and burnout in the contacts with patients and the marital status of the subjects and burnout in relations with patients. For all other variables, statistically significant differences were found at the significance level of $p<0.05$ (Table II). Interrelationships determining the direction and strength of the relationship between selected variables were evaluated using the Spearman rank correlation test. The process of presenting the results was based on the classification of Guilford's correlation force. A weakly negative, yet statistically significant relationship was found by submitting the results of Spearman's rank correlation test between the financial situation of the studied group and occupational burnout observed in all three components of burnout: personal $(r=-0.20 ; p<0.001)$, related to work $(r=-0.19 ; p<0.001)$ and in relationships with patients $(r=-0.19 ; p<0.001)$. This indicated that nurses who more often experience burnout syndrome more often have a worse financial situation. The results of the analyses showed that the remaining observed relationships between the variables showed a weak, statistically significant correlation. Detailed data are presented in Table II.

\section{Burnout predictors}

In the next step of statistical analyses, the multiple regression method was used to search for predictors for three components of occupational burnout (dependent variables - explained). The first type of analysis determined whether global self-esteem is a predictor of occupational burnout. The second analysis identified those sociodemographic variables and variables related to the work environment that allow the occurrence of burnout syndrome to be predicted. The pool of analyzed independent variables (explanatory variables) included global self-esteem, age, marital status, financial situation, education, years of work experience, work system, workplace and ward/clinic profile. The obtained results of the regression analysis showed that global self-esteem was a predictor of professional burnout of nurses in all three areas. In the case of personal burnout, it explained $7 \%$ of the variance of the dependent variable, while in the case of burnout at work it explained only $2 \%$ and also $2 \%$ for burnout in contacts with patients. Taking into account particular sociodemographic variables and those related to the work environment, regression analyses showed that the predictors of professional burnout of nurses were two variables: financial situa- 
Table II. Significance of the relationship between components of burnout and demographic and work-related factors

\begin{tabular}{|c|c|c|c|c|c|}
\hline \multirow[t]{3}{*}{ Variables } & & \multirow{3}{*}{$\begin{array}{c}N=1,806 \\
(\%)\end{array}$} & \multicolumn{3}{|c|}{ Test values } \\
\hline & & & $\begin{array}{l}\chi^{2} \text { test of } \\
\text { indepen- } \\
\text { dence }\left(\chi^{2}\right)\end{array}$ & $\begin{array}{l}\text { Kruskal- } \\
\text { Wallis test } \\
\quad(H)\end{array}$ & $\begin{array}{l}\text { Spearman's } \\
\text { rank cor- } \\
\text { relation }(r)\end{array}$ \\
\hline & & & \multicolumn{3}{|c|}{$P$-value } \\
\hline \multicolumn{6}{|c|}{ Significance of relationship between personal burnout and demographic and work-related factors: } \\
\hline \multirow[t]{4}{*}{ Age } & $\leq 30$ & $121(6.7)$ & \multirow{4}{*}{$\begin{array}{l}12.25 \\
0.06\end{array}$} & \multirow{4}{*}{$\begin{array}{c}10.11 \\
0.02\end{array}$} & \multirow{4}{*}{$\begin{array}{l}0.04 \\
0.07\end{array}$} \\
\hline & $31-40$ & $394(21.8)$ & & & \\
\hline & $41-50$ & $862(47.7)$ & & & \\
\hline & $\geq 51$ & $429(23.8)$ & & & \\
\hline \multirow{4}{*}{$\begin{array}{l}\text { Marital } \\
\text { status }\end{array}$} & Unmarried & $168(9.3)$ & \multirow{4}{*}{$\begin{array}{l}8.21 \\
0.22\end{array}$} & \multirow{4}{*}{$\begin{array}{l}3.24 \\
0.35\end{array}$} & \multirow{4}{*}{$\begin{array}{l}0.03 \\
0.11\end{array}$} \\
\hline & Married & $1414(78.3)$ & & & \\
\hline & Widowed & $38(2.1)$ & & & \\
\hline & Divorced & $186(10.3)$ & & & \\
\hline \multirow{5}{*}{$\begin{array}{l}\text { Financial } \\
\text { situation }\end{array}$} & Very good & $48(2.7)$ & \multirow{5}{*}{$\begin{array}{l}83.11 \\
0.001\end{array}$} & \multirow{5}{*}{$\begin{array}{l}78.26 \\
0.001\end{array}$} & \multirow{5}{*}{$\begin{array}{l}-0.20 \\
0.001\end{array}$} \\
\hline & Good & $567(31.4)$ & & & \\
\hline & Sufficient & $774(42.8)$ & & & \\
\hline & Poor & $336(18.6)$ & & & \\
\hline & Very poor & $81(4.5)$ & & & \\
\hline \multirow[t]{5}{*}{ Education } & Secondary medical & $665(36.8)$ & \multirow{5}{*}{$\begin{array}{l}19.05 \\
0.02\end{array}$} & \multirow{5}{*}{$\begin{array}{l}16.69 \\
0.002\end{array}$} & \multirow{5}{*}{$\begin{array}{l}-0.07 \\
0.001\end{array}$} \\
\hline & College/post-secondary & $371(20.5)$ & & & \\
\hline & Higher - bachelor of nursing & $458(25.4)$ & & & \\
\hline & Higher - master of nursing & $214(11.9)$ & & & \\
\hline & $\begin{array}{c}\text { Other higher, applicable in } \\
\text { healthcare units }\end{array}$ & $98(5.4)$ & & & \\
\hline \multirow{4}{*}{$\begin{array}{l}\text { Years of } \\
\text { experience } \\
\text { in the } \\
\text { profession }\end{array}$} & $\leq 10$ & $248(13.7)$ & \multirow{4}{*}{$\begin{array}{c}10.87 \\
0.09\end{array}$} & \multirow{4}{*}{$\begin{array}{l}9.039 \\
0.03\end{array}$} & \multirow{4}{*}{$\begin{array}{l}0.04 \\
0.04\end{array}$} \\
\hline & $11-20$ & $450(24.9)$ & & & \\
\hline & $21-30$ & $734(40.7)$ & & & \\
\hline & $\geq 31$ & $374(20.7)$ & & & \\
\hline \multirow{2}{*}{$\begin{array}{l}\text { Shift } \\
\text { system }\end{array}$} & Single shift & $439(24.3)$ & \multirow{2}{*}{$\begin{array}{l}1.61 \\
0.44\end{array}$} & 1.40 & 0.02 \\
\hline & $\begin{array}{c}\text { Multiple shifts (including work } \\
\text { at night) }\end{array}$ & $1367(75.7)$ & & 0.23 & 0.23 \\
\hline Type of & Managerial & $193(10.7)$ & 13.61 & 13.58 & 0.08 \\
\hline position & Regular & $1613(89.3)$ & 0.001 & 0.001 & 0.001 \\
\hline Ward/ & Preventive clinic & $804(44.5)$ & 14.17 & 8.18 & -0.06 \\
\hline clinic & Treatment clinic & $574(31.8)$ & 0.03 & 0.05 & 0.008 \\
\hline & $\begin{array}{c}\text { Intensive care, anesthesiology, } \\
\text { operating theater }\end{array}$ & $245(13.6)$ & & & \\
\hline & $\begin{array}{l}\text { Outpatient care, diagnostic } \\
\text { department }\end{array}$ & $183(10.1)$ & & & \\
\hline Significance & f relationship between work-rela & nout and den & hic and wor & elated factor & \\
\hline Age & $\leq 30$ & $121(6.7)$ & 33.87 & 31.05 & 0.10 \\
\hline & $31-40$ & $394(21.8)$ & 0.001 & 0.001 & 0.001 \\
\hline & $41-50$ & $862(47.7)$ & & & \\
\hline & $\geq 51$ & $429(23.8)$ & & & \\
\hline
\end{tabular}


Table II. Cont.

\begin{tabular}{|c|c|c|c|c|c|}
\hline \multirow[t]{3}{*}{ Variables } & & \multirow{3}{*}{$\begin{array}{c}N=1,806 \\
(\%)\end{array}$} & \multicolumn{3}{|c|}{ Test values } \\
\hline & & & $\begin{array}{l}\chi^{2} \text { test of } \\
\text { indepen- } \\
\text { dence }\left(\chi^{2}\right)\end{array}$ & $\begin{array}{l}\text { Kruskal- } \\
\text { Wallis test } \\
(H)\end{array}$ & $\begin{array}{l}\text { Spearman's } \\
\text { rank cor- } \\
\text { relation }(r)\end{array}$ \\
\hline & & & \multicolumn{3}{|c|}{$P$-value } \\
\hline \multirow{4}{*}{$\begin{array}{l}\text { Marital } \\
\text { status }\end{array}$} & Unmarried & $168(9.3)$ & \multirow{4}{*}{$\begin{array}{c}12.66 \\
0.07\end{array}$} & \multirow{4}{*}{$\begin{array}{c}10.87 \\
0.02\end{array}$} & \multirow{4}{*}{$\begin{array}{c}0.06 \\
0.002\end{array}$} \\
\hline & Married & $1414(78.3)$ & & & \\
\hline & Widowed & $38(2.1)$ & & & \\
\hline & Divorced & $186(10.3)$ & & & \\
\hline \multirow{5}{*}{$\begin{array}{l}\text { Financial } \\
\text { situation }\end{array}$} & Very good & $48(2.7)$ & \multirow{5}{*}{$\begin{array}{l}79.08 \\
0.001\end{array}$} & \multirow{5}{*}{$\begin{array}{l}70.65 \\
0.001\end{array}$} & \multirow{5}{*}{$\begin{array}{l}-0.19 \\
0.001\end{array}$} \\
\hline & Good & $567(31.4)$ & & & \\
\hline & Sufficient & $774(42.8)$ & & & \\
\hline & Poor & $336(18.6)$ & & & \\
\hline & Very poor & $81(4.5)$ & & & \\
\hline \multirow[t]{5}{*}{ Education } & Secondary medical & $665(36.8)$ & \multirow{5}{*}{$\begin{array}{l}41.41 \\
0.001\end{array}$} & \multirow{5}{*}{$\begin{array}{l}36.69 \\
0.001\end{array}$} & \multirow{5}{*}{$\begin{array}{l}-0.12 \\
0.001\end{array}$} \\
\hline & College/post-secondary & $371(20.5)$ & & & \\
\hline & Higher - bachelor of nursing & $458(25.4)$ & & & \\
\hline & Higher - master of nursing & $214(11.9)$ & & & \\
\hline & $\begin{array}{l}\text { Other higher, applicable in } \\
\text { healthcare units }\end{array}$ & $98(5.4)$ & & & \\
\hline \multirow{4}{*}{$\begin{array}{l}\text { Years of } \\
\text { experience } \\
\text { in the } \\
\text { profession }\end{array}$} & $\leq 10$ & $248(13.7)$ & \multirow{4}{*}{$\begin{array}{l}54.73 \\
0.001\end{array}$} & \multirow{4}{*}{$\begin{array}{l}48.07 \\
0.001\end{array}$} & \multirow{4}{*}{$\begin{array}{c}0.13 \\
0.001\end{array}$} \\
\hline & $11-20$ & $450(24.9)$ & & & \\
\hline & $21-30$ & $734(40.7)$ & & & \\
\hline & $\geq 31$ & $374(20.7)$ & & & \\
\hline \multirow{2}{*}{$\begin{array}{l}\text { Shift } \\
\text { system }\end{array}$} & Single shift & $439(24.3)$ & \multirow{2}{*}{$\begin{array}{l}5.40 \\
0.06\end{array}$} & \multirow{2}{*}{$\begin{array}{l}5.39 \\
0.02\end{array}$} & \multirow{2}{*}{$\begin{array}{l}0.05 \\
0.02\end{array}$} \\
\hline & $\begin{array}{l}\text { Multiple shifts (including work } \\
\text { at night) }\end{array}$ & $1,367(75.7)$ & & & \\
\hline \multirow{2}{*}{$\begin{array}{l}\text { Type of } \\
\text { position }\end{array}$} & Managerial & $193(10.7)$ & \multirow{2}{*}{$\begin{array}{l}10.32 \\
0.005\end{array}$} & \multirow{2}{*}{$\begin{array}{l}10.28 \\
0.001\end{array}$} & 0.07 \\
\hline & Regular & $1,613(89.3)$ & & & \\
\hline Ward/ & Preventive clinic & $804(44.5)$ & 17.04 & 5.97 & -0.005 \\
\hline clinic & Treatment clinic & $574(31.8)$ & 0.009 & 0.11 & 0.02 \\
\hline & $\begin{array}{c}\text { Intensive care, anesthesiology, } \\
\text { operating theater }\end{array}$ & $245(13.6)$ & & & \\
\hline & $\begin{array}{l}\text { Outpatient care, diagnostic } \\
\text { department }\end{array}$ & $183(10.1)$ & & & \\
\hline Significance & f relationship between burnout in & acts with patie & d demograp & and work-re & ated factors: \\
\hline Age & $\leq 30$ & $121(6.7)$ & 16.94 & 14.81 & 0.04 \\
\hline & $31-40$ & $394(21.8)$ & 0.009 & 0.002 & 0.05 \\
\hline & $41-50$ & $862(47.7)$ & & & \\
\hline & $\geq 51$ & $429(23.8)$ & & & \\
\hline Marital & Unmarried & $168(9.3)$ & 4.68 & 3.20 & 0.03 \\
\hline status & Married & $1414(78.3)$ & 0.58 & 0.36 & 0.20 \\
\hline & Widowed & $38(2.1)$ & & & \\
\hline & Divorced & $186(10.3)$ & & & \\
\hline
\end{tabular}


Table II. Cont.

\begin{tabular}{|c|c|c|c|c|c|}
\hline \multirow[t]{3}{*}{ Variables } & & \multirow{3}{*}{$\begin{array}{c}N=1,806 \\
(\%)\end{array}$} & \multicolumn{3}{|c|}{ Test values } \\
\hline & & & $\begin{array}{l}\chi^{2} \text { test of } \\
\text { indepen- } \\
\text { dence }\left(\chi^{2}\right)\end{array}$ & $\begin{array}{c}\text { Kruskal- } \\
\text { Wallis test } \\
(H)\end{array}$ & $\begin{array}{c}\text { Spearman's } \\
\text { rank cor- } \\
\text { relation }(r)\end{array}$ \\
\hline & & & \multicolumn{3}{|c|}{$P$-value } \\
\hline \multirow{5}{*}{$\begin{array}{l}\text { Financial } \\
\text { situation }\end{array}$} & Very good & $48(2.7)$ & \multirow{5}{*}{$\begin{array}{l}78.41 \\
0.001\end{array}$} & \multirow{5}{*}{$\begin{array}{l}71.42 \\
0.001\end{array}$} & \multirow{5}{*}{$\begin{array}{l}-0.19 \\
0.001\end{array}$} \\
\hline & Good & $567(31.4)$ & & & \\
\hline & Sufficient & $774(42.8)$ & & & \\
\hline & Poor & $336(18.6)$ & & & \\
\hline & Very poor & $81(4.5)$ & & & \\
\hline \multirow[t]{5}{*}{ Education } & Secondary medical & $665(36.8)$ & \multirow{5}{*}{$\begin{array}{l}22.28 \\
0.004\end{array}$} & \multirow{5}{*}{$\begin{array}{l}28.16 \\
0.001\end{array}$} & \multirow{5}{*}{$\begin{array}{l}-0.09 \\
0.001\end{array}$} \\
\hline & College/post-secondary & $371(20.5)$ & & & \\
\hline & Higher - bachelor of nursing & $458(25.4)$ & & & \\
\hline & Higher - master of nursing & $214(11.9)$ & & & \\
\hline & $\begin{array}{c}\text { Other higher, applicable in } \\
\text { healthcare units }\end{array}$ & $98(5.4)$ & & & \\
\hline \multirow{4}{*}{$\begin{array}{l}\text { Years of } \\
\text { experience } \\
\text { in the } \\
\text { profession }\end{array}$} & $\leq 10$ & $248(13.7)$ & \multirow{4}{*}{$\begin{array}{l}36.71 \\
0.001\end{array}$} & \multirow{4}{*}{$\begin{array}{l}29.32 \\
0.001\end{array}$} & \multirow{4}{*}{$\begin{array}{c}0.0081 \\
0.003\end{array}$} \\
\hline & $11-20$ & $450(24.9)$ & & & \\
\hline & $21-30$ & $734(40.7)$ & & & \\
\hline & $\geq 31$ & $374(20.7)$ & & & \\
\hline \multirow{2}{*}{$\begin{array}{l}\text { Shift } \\
\text { system }\end{array}$} & Single shift & $439(24.3)$ & \multirow{2}{*}{$\begin{array}{l}6.41 \\
0.04\end{array}$} & \multirow{2}{*}{$\begin{array}{l}6.11 \\
0.02\end{array}$} & \multirow{2}{*}{$\begin{array}{l}0.05 \\
0.01\end{array}$} \\
\hline & $\begin{array}{c}\text { Multiple shifts (including work } \\
\text { at night) }\end{array}$ & $1,367(75.7)$ & & & \\
\hline \multirow{2}{*}{$\begin{array}{l}\text { Type of } \\
\text { position }\end{array}$} & Managerial & $193(10.7)$ & \multirow{2}{*}{$\begin{array}{c}9.26 \\
0.009\end{array}$} & \multirow{2}{*}{$\begin{array}{c}8.53 \\
0.003\end{array}$} & \multirow{2}{*}{$\begin{array}{c}0.07 \\
0.003\end{array}$} \\
\hline & Regular & $1,613(89.3)$ & & & \\
\hline \multirow{4}{*}{$\begin{array}{l}\text { Ward/ } \\
\text { clinic } \\
\text { profile }\end{array}$} & Preventive clinic & $804(44.5)$ & \multirow{4}{*}{$\begin{array}{l}9.54 \\
0.14\end{array}$} & \multirow{4}{*}{$\begin{array}{l}6.49 \\
0.09\end{array}$} & \multirow{4}{*}{$\begin{array}{c}-0.04 \\
0.04\end{array}$} \\
\hline & Treatment clinic & $574(31.8)$ & & & \\
\hline & $\begin{array}{c}\text { Intensive care, anesthesiology, } \\
\text { operating theater }\end{array}$ & $245(13.6)$ & & & \\
\hline & $\begin{array}{c}\text { Outpatient care, diagnostic } \\
\text { department }\end{array}$ & $183(10.1)$ & & & \\
\hline
\end{tabular}

tion and work experience. It is worth noting that both variables have very low predictive power. The financial situation is a predictor of personal burnout, explaining $3 \%$ of the variance of the dependent variable, burnout at work: $4 \%$, and burnout in relations with patients: $4 \%$. The predictive role for burnout at work is occupational experience, which explained $2 \%$ of the variance of the dependent variable. A comparison of relevant predictors of occupational burnout is presented in Table III.

\section{Discussion}

Burnout syndrome is included in the International Statistical Classification of Diseases and Related Health Problems (International Statistical Classification of Diseases and Related Health Problems-ICD-10), but many researchers are still inconsistent in defining this phenomenon and diagnosing axial symptoms, including measurement methods [12, 14, 15]. Kristensen et al. demonstrated that professionally active nurses who indicated work-related burnout and burnout in contact with patients had a much lower overall severity $[2,12]$. The results of the available studies indicate that there are many factors that are associated directly or indirectly with burnout. In the current study, almost half (47\%) of the nurses showed a global sense of self-esteem on an average level, but $23 \%$ of respondents obtained low scores. In the authors' own research, when analyzing the predictive role of global self-esteem for the consequences of the burnout syndrome experienced, it was found that global self-esteem plays a key role, especially in preventing the symptoms 
Table III. Summary of regression - burnout predictors

\begin{tabular}{|c|c|c|c|c|c|c|}
\hline Variables & $R^{2}$ & Beta & B & Error $\beta$ & $t$ & $P$-value \\
\hline \multicolumn{7}{|c|}{ Predictors of personal burnout: } \\
\hline Global self-esteem & 0.07 & -0.24 & -0.26 & 0.02 & -10.64 & 0.0001 \\
\hline Financial situation & 0.03 & -0.16 & -0.15 & 0.02 & -7.27 & 0.0001 \\
\hline Constant value & & & 2.40 & 0.16 & 14.72 & 0.0001 \\
\hline \multicolumn{7}{|c|}{$R=0.33 ; R^{2}=0.10 ;$ corrected $R^{2}=0.11$} \\
\hline \multicolumn{7}{|c|}{ Predictors of work related burnout: } \\
\hline Financial situation & 0.04 & -0.17 & -0.16 & 0.02 & -7.33 & 0.0001 \\
\hline Global self-esteem & 0.02 & -0.15 & -0.17 & 0.03 & -6.58 & 0.0001 \\
\hline Work experience & 0.02 & 0.14 & 0.12 & 0.02 & 6.17 & 0.0001 \\
\hline Constant value & & & 2.39 & 0.10 & 23.70 & 0.0001 \\
\hline \multicolumn{7}{|c|}{$R=0.28 ; R^{2}=0.08 ;$ corrected $R^{2}=0.09$} \\
\hline \multicolumn{7}{|c|}{ Predictors of burnout in contact with patients: } \\
\hline Financial situation & 0.04 & -0.16 & -0.15 & 0.02 & -6.99 & 0.0001 \\
\hline Global self-esteem & 0.02 & -0.13 & -0.15 & 0.03 & -5.55 & 0.0001 \\
\hline Constant value & & & 2.24 & 0.14 & 15.52 & 0.0001 \\
\hline
\end{tabular}

Statistically significant: $p<0.001 . R$ - correlation coefficient, $R^{2}-$ multiple determination coefficient, Beta - standardized regression coefficient, $B$-non-standardized regression coefficient, Error $B$ - error of non-standardized regression coefficient, $t-t$-test value.

of personal burnout. This suggests that developing personal resources and deriving benefits from them can be important in the prevention of burnout syndrome. However, the issue is not entirely clear and requires further scientific research, such as the estimation of hidden self-esteem, shown spontaneously, automatically and without self-reflection. The results of research conducted among 212 nurses in Germany using Rosenberg's Self-Esteem Scale indicated that nurses who had an academic degree displayed a statistically significantly higher level of self-esteem than nurses without an academic education. The type of professional training may therefore have a direct effect on self-esteem, thus offering a myriad of potential benefits to both nurses and patients [16]. Other studies have shown that the low self-esteem of nurses induces a service sabotage attitude, and that these nurses are less developed, both emotionally and chronologically, demonstrate less experience and have less education compared to their typical counterparts [17]. Recognizing the great importance of global self-esteem in the prevention of work-related burnout among nurses, it appears that strengthening self-esteem through micro-interventions, such as training or individual sessions targeted at the development of self-esteem resources, should be recommended. Based on study results provided by Hildingsson et al., the strongest associations between burnout and midwives' characteristics were age < 40, work and work experience < 10 years [18]. Some researchers have indicated that the level of burnout increases with age $[19,20]$. Others, however, do not support this thesis [6]. Similar results were obtained in the present study. There was a small positive, significant relationship between the age of nurses and personal burnout. Hildingsson et al. found that conflict with co-workers and/or managers, as well as worries about the future and one's health were other relevant explanatory variables. Those authors also found that one in three midwives had considered leaving the profession [18]. Moreover, Szpakowski et al. noted the very important problem of migration of young nurses and physicians from Poland, which should be a key element in the personnel policy in the Polish health-care system [21]. Work-related burnout may also aggravate the personnel situation in the nursing sub-system.

Several studies have clearly shown that the income of nurses is closely linked to burnout. Tekindal et al. emphasized the negative relationship of the financial situation of nurses with a sense of emotional exhaustion [22]. Furthermore, excessive workload had a negative correlation with a sense of personal achievement. The most important findings in the study of Demir et al. were 
that higher education level, work experience and social status reduce burnout, and that working night shifts increases it [21]. The current research has shown that the appearance of burnout symptoms in the context of work is influenced by the following factors: financial situation, work experience, education, age, marital status, the shift system and the type of position held. Several studies by other authors have indicated a positive relationship between work experience and burnout [2, 22, 23]. In a study conducted by Hoffman and Scott it was found that irregular working hours and, above all, the 12-hour shift system, had a negative impact on health and the level of job satisfaction. Salary, autonomy and professional status were shown to determine career satisfaction in all studies [24]. It is worth noting another Polish study which showed that the main factor moderating the burnout syndrome of oncology nurses was their level of education, which also impacted their level of empathy [25]. Sadovich found that a high level of job satisfaction and positive reception of the factors affecting the process of working reduce the occurrence of professional burnout syndrome [26]. In the current study, nurses in managerial positions tend to do better in the work environment and show fewer symptoms of burnout, compared to nurses employed in other positions working in the nursing subsystem. Similar conclusions were drawn in Danish studies [27]. Of key importance in providing comprehensive patient care were interpersonal social skills and the atmosphere in the workplace. In the current study, it was demonstrated that around $44 \%$ of nurses felt that they were free from symptoms of burnout in contact with patients. Noteworthy findings of other authors were that nurses who are more burdened with work and more emotionally exhausted report having more problems in contacts with patients, more frequent conflicts in the therapeutic team, lack of faith in their competence and conflicts between work and private life [28]. A study conducted in South Africa of a group of 818 nurses showed that not only the experience of depletion of emotional resources but also feelings of depersonalization were related to stress due to job requirements and a lack of official support, a focus on venting emotions as a coping strategy and a weak sense of coherence. A strong sense of coherence and active-coping strategies predicted good work engagement [29]. As shown in the "Social Diagnosis", among 39 comparable professional groups, nurses in Poland are currently $16^{\text {th }}$ in terms of overall quality of life [1]. De Oliveira et al., based on their literature review, found that the following interventions were most frequently applied in the prevention of work-related burnout: yoga, cognitive coping strategies, compassion fatigue program, systematic clinical supervision, meditation, a web-based stress management pro- gram and a mental and psychological empowerment program [30].

The results of the study confirm the need to implement prophylactic burnout programs, including practical training, which allow individual psychological resource development, including global self-esteem. Based on the current research, it can be concluded that occupational hazard prevention programs for nurses should be permanently integrated into incentive systems that are an integral part of an efficient and effective nursing management approach. The interventions presented by de Oliveira et al. may also be included in prophylactic programs [30].

This study has its strengths as well as limitations. This is the first Polish study analyzing the issue of global self-esteem as a personal resource conducted on a very large group of 1,806 nurses from 23 hospitals. Self-evaluation techniques were used to evaluate the described variables. The studies were of a cross-sectional nature, so the presence of causal relationships between the variables should be considered with care.

In conclusion, about a quarter of the respondents indicated the presence of burnout symptoms. Polish nurses are more likely to experience personal burnout than work-related burnout and burnout in contacts with patients. The results of global self-esteem showed differentiation in the study group. The vast majority of nurses have average or high levels of global self-esteem. Global self-esteem has been shown to play an important role in predicting burnout and it explains $7 \%$ of the variance of the dependent variable. Demographic and work environment-related variables exerted various effects on the occurrence of professional burnout symptoms and the predominant factor was the financial situation of the respondents. Developing personal resources and deriving benefits from them may be important in the prevention of burnout syndrome. It is justified to carry out preventive measures in the workplace to protect nurses from burnout.

\section{Conflict of interest}

The authors declare no conflict of interest.

\section{References}

1. Walkiewicz M, Sowińska K, Tartas M. Wypalenie zawodowe wśród personelu medycznego - przegląd literatury [Burnout among medical staff - literature review] Prz Lek 2014; 71: 263-9.

2. Kristensen TS, Borritz M, Villadsen E, Christensen KB. The Copenhagen Burnout Inventory: a new tool for the assessment of burnout. Work Stress 2005; 19: 192-207.

3. Berat N, Jelit D, Popov B. Serbian version of the Work Burnout Scale from the Copenhagen Burnout Inventory: adaptation and psychometric properties. Primenjena Psihologija 2016; 9: 177-98. 
4. Ogińska-Bulik N. Związek między wypaleniem zawodowym i wtórnym stresem traumatycznym wśród pielęgniarek pracujących w opiece paliatywnej [The relationship between job burnout and secondary traumatic stress among nurses working in palliative care]. Psychiatria 2018; 15: 63-9.

5. Henriksen L, Lukasse M. Burnout among Norwegian midwives and the contribution of personal and work-related factors: a cross-sectional study. Sex Reprod Healthc 2016; 9: 42-7.

6. Kowalski C, Ommen O, Driller E, et al. Burnout in nurses - the relationship between social capital in hospitals and emotional exhaustion. J Clin Nurs 2010; 19: 1654-63.

7. Xie Z, Wang A, Chen B. Nurse burnout and its association with occupational stress in a cross-sectional study in Shanghai. J Adv Nurs 2011; 67: 1537-46.

8. Shamali M, Shahriari M, Babaii A, Abbasinia M. Comparative study of job burnout among critical care nurses with fixed and rotating shift schedules. Nurs Midwifery Stud 2015; 4: e27766.

9. Jordanab K, Fenwickab J, Slavinab V, Sidebothama M Gamblea J. Level of burnout in a small population of Australian midwives. Women Birth 2013; 6: 125-32.

10. Cañadas-De la Fuente GA, Vargas C, San Luis C, García I, Cañadas GR, De la Fuente El. Risk factors and prevalence of burnout syndrome in the nursing profession. Int J Nurs Stud 2015; 52: 240-9.

11. Twenge J. The socially excluded self. In: The self. Sedikides C, Spencer SJ (eds.). Psychology Press, New York 2007; 311-24.

12. Nowakowska I. Zarządzanie jakością pracy zespołu pielęgniarskiego w szpitalu [Work quality of nursing team at the hospital - dissertation]. Uniwersytet Medyczny im. Marcinkowskiego K. Poznań 2011.

13. Dzwonkowska I, Lachowicz-Tabaczek K, Łaguna M. Samoocena i jej pomiar. Polska adaptacja skali SES $M$ Rosenberga [Self-esteem and its measurement. Polish adaptation of the M. Rosenberg SES scale]. Pracownia Testów Psychologicznych, Warsaw 2008.

14. Pużyński S, Wciorka J. ICD-10 Międzynarodowa Klasyfikacja Chorób i Problemów Zdrowotnych [ICD-10 International Statistical Classification of Diseases and Related Health Problems]. Centrum Systemów Informacyjnych Ochrony Zdrowia, Warsaw 2008.

15. Baka Ł, Basińska B. Psychometryczne właściwości polskiej wersji Oldenburskiego Kwestionariusza Wypale nia Zawodowego (OLBI) [Psychometric properties of the Polish version of the Oldenburg Burnout Inventory (OLBI)]. Med Pr 2016; 67: 29-41.

16. Van Eckert S, Gaidys U, Martin CR. Self-esteem among German nurses: does academic education make a difference? J Psychiatr Ment Health Nurs 2012; 19: 903-10.

17. Ling IL, Marshall R, Xu Y, Lin WY. Daypatient-induced service sabotage behavior: the issue of self-esteem of hospital nurses. Health Market O 2014; 31: 213-30.

18. Hildingsson I, Westlund K, Wiklundde I. Burnout in Swedish midwives. Sex Reprod Healthc 2013; 4: 87-91.

19. Lin F, St John W, McVeigh C. Burnout among hospital nurses in China. J Nurs Manag 2009; 17: 294-301.

20. Meeusen V, Van Dam K, Brown-Mahoney C, Van Zundert A, Knape $H$. Burnout, psychosomatic symptoms and job satisfaction among Dutch nurse anaesthetists: a survey. Acta Anaesthesiol Scand 2010; 54: 616-21.

21. Szpakowski R, Dykowska G, Fronczak A, Zając P, Czerw A. Migrations of nurses and doctors from Poland: data for the years 2014-2020 based on a sample of the capital city of Warsaw. Arch Med Sci 2019; 15: 811-20.
22. Tekindal B, Tekindal MA, Pinar G, Ozturk F, Alan S. Nurses' burnout and unmet nursing care needs of patients' relatives in a Turkish State Hospital. Int J Nurs Pract 2012; 18: 68-76.

23. Maslach C, Schaufeli WB, Leiter MP. Job burnout. Annu Rev Psychol 2001; 52: 397-422.

24. Hoffman AJ, Scott LD. Role stress and career satisfaction among registered nurses by work shift patterns. J Nurs Adm 2003; 33: 337-42.

25. Lochmajer MA. Poziom empatii i wykształcenia jako czynniki moderujące syndrom wypalenia zawodowego $u$ pielęgniarek onkologicznych [The level of empathy and education as factors moderating the syndrome of burnout in oncology nurses]. Med Paliat 2015; 7 : 268-75.

26. Sadovich JM. Work excitement in nursing: an examination of the relationship between work excitement and burnout. Nurs Econ 2005; 23: 91-6.

27. Borritz M. Burnout In Human Service Work - Causes and Consequences. 2006 [cited 2019 March 22]. Available from: www.ami.dk./upload/MB-phd.pdf.

28. Alacacioglu A, Yavuzsen T, Dirioz M, Oztop I, Yilmaz U. Burnout in nurses and physicians working at an oncology department. Psychooncology 2009; 18: 543-8.

29. Van der Colff JJ, Rothmann S. Occupational stress, sense of coherence, coping, burnout and work engagement of registered nurses in South Africa. SAJIP 2009; 35: 1-10.

30. de Oliveira SM, de Alcantara Sousa LV, Vieira Gadelha MDS, do Nascimento VB. Prevention actions of burnout syndrome in nurses: an integrating literature review. Clin Pract Epidemiol Ment Health 2019; 15: 64-73. 